\title{
Ruling on Rituals: Courts of Law and Religious Practices in Contemporary Hinduism
}

\section{Gilles Tarabout}

\section{(2) OpenEdition \\ Journals}

Electronic version

URL: https://journals.openedition.org/samaj/4451

DOI: 10.4000/samaj.4451

ISSN: 1960-6060

\section{Publisher}

Association pour la recherche sur l'Asie du Sud (ARAS)

\section{Electronic reference}

Gilles Tarabout, "Ruling on Rituals: Courts of Law and Religious Practices in Contemporary Hinduism", South Asia Multidisciplinary Academic Journal [Online], 17 | 2018, Online since 29 January 2018, connection on 21 September 2021. URL: http://journals.openedition.org/samaj/4451 ; DOI: https:// doi.org/10.4000/samaj.4451

This text was automatically generated on 21 September 2021.

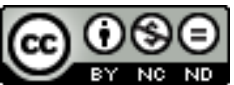

This work is licensed under a Creative Commons Attribution-NonCommercial-NoDerivatives 4.0 International License. 


\title{
Ruling on Rituals: Courts of Law and Religious Practices in Contemporary Hinduism
}

\author{
Gilles Tarabout
}

1 Scholars have regularly pointed out that in secular states the involvement of courts in religious matters is commonplace. There are two main reasons for this. One is that in the modern state, "religion is, in part, constituted by means of law, but simultaneously as something that is constituted to stand at arm's length from the law" (Lambek 2013:1). ${ }^{1}$ The second follows on from the first: as Jurinski (2004:3) remarks in the case of the USA, "the courts have become arbiters of what kinds of restrictions the government can impose on religious practice, and what role religion will play in public life." In fact, the courts seldom restrict themselves to being keepers of religious boundaries. As Sen (2007:6) observes, comparing India and the United States, "the line between interpretation of law and legislation often gets blurred in Supreme Court rulings. ... This has meant that the Court ... actively intervenes and shapes public discourse." Indeed, as early as the 1970s, Marc Galanter clearly pointed out two possible ways in which the law may exercise its control over religion, which he called "the mode of limitation" and "the mode of intervention":

By limitation I refer to the shaping of religion by promulgating public standards and by defining the field in which these secular public standards shall prevail, overruling conflicting assertions of religious authority. By intervention I refer to something beyond this-to an attempt to grasp the levers of religious authority and to reformulate the religious tradition from within, as it were (Galanter 1971:480).

This paper sets out to contribute to the study of how Indian courts of law have a hand in shaping religion and more particularly Hinduism. While entirely in agreement with Galanter, my specific purpose is to suggest that various forms of "limitation" ensuing from the very fundamentals of Common law (applying to India) directly lead, on their own, to far-reaching "interventions" in religious traditions.

2 There is considerable scholarship on relationships between law and religion in India, which has followed various lines of enquiry. Authors have pointed out the legacy of 
British policies in taking over the management of religious institutions in the name of administrative rationalization; the history and political consequences of Private Laws; the Constitutional protection and regulation of the freedom of religion (Articles 25 and 26); the role of the Courts in implementing this Constitutional mandate; or the reformist agenda that some judges may try to promote. In the first part of this paper I sum up the aspects of these studies that mainly pertain to politics of secularism concerning Hindu temples. Then, in a second section, I turn to the comparatively less explored issue of the impact on religious practices of the mere imposition of legal categories and requirements. How does the legal process by itself and beyond any particular policies, beyond even a secularist agenda, shape religious practices (Hindu, Muslim, Christian)? While acknowledging that such legal "determinism" is completely entangled in general policies or judges' personal values, I nevertheless wish to point out a few systemic properties of modern law that have a decisive effect in shaping religion-although my argument also applies to Islam and Christianity, my study focuses on Hinduism. ${ }^{3}$

3 This paper relies on judgments of the upper courts of India with a special focus on religious institutions, not personal law. ${ }^{4}$ These judgments constitute an extremely rich corpus of texts in which it is possible to distinguish various levels and means of legal action concerning religion-related issues.

\section{The politics of secularism: an overview}

\section{Secularization as individualization}

Although India presents features of its own, many issues are common to secular states throughout the world where legal conceptions of religion are anchored in the distinction the law makes between "private" and "public" domains. This was already the case in India during British rule and was subsequently reinforced in the Constitution after Independence. The "Fathers of the Constitution," according to a former Chief Justice of India, "placed the individual at the centre of the Constitutional scheme" (Bhagwati 2005:40), ${ }^{5}$ though not without a debate (Dhavan 1987:209). As far as religion is concerned, the Preamble to the Constitution ensures all citizens the liberty of "thought, expression, belief, faith and worship"; and Article 25 (1) stipulates that:

(1) Subject to public order, morality and health and to the other provisions of this Part, all persons are equally entitled to freedom of conscience and the right freely to profess, practise and propagate religion-my emphasis) (Constitution of India 1950: Art.25(1))

This individual character of religious freedom has been further developed in various upper court decisions. For instance, in 1995, the Supreme Court of India referred to Halsbury's Laws of England ( $1^{\text {st }}$ ed. 1907, regularly reedited and updated since then) according to which "A church is formed by the voluntary association of individuals" and extended this conception to all religious bodies (Most. Rev. P.M.A. Metropolitan 1995:\$35). Society, and religion, is thus seen as being made up of an addition of individuals, a presupposition that is widely at odds with the holistic view projected by most religious systems: placing the individual at the center of legal action may foster, by itself, profound changes in religious attitudes and practices. As Maya Warrier (2003:214) pointed out, secularization in general may be linked to a "retreat of religion from public life":

By secularization I mean therefore a decline in the public, community-affirming and socially-binding aspect of religion, and a growing trend towards the 
internalization of faith such that it is personal choice, inner spiritual striving and self-fulfillment that become central to religious life rather than the affirmation of shared community orientations, affiliations, aspirations and identities.

Such an individualistic perspective found its way, for instance, into a definition of religion given by the High Court of Bombay, which ruled that "whatever binds a man to his own conscience and whatever moral or ethical principle regulate[s] the lives of men believing in that theistic conscience or religious belief that alone can constitute religion as understood in the Constitution" (Ratilal Panachand Gandhi 1952:\$4). However, this definition, solely in terms of conscience, was felt to be ill-adapted to Indian realities and was later broadened by the Supreme Court in the so-called "Shirur Mutt case":

A religion may not only lay down a code of ethical rules for its followers to accept, it might prescribe rituals and observances, ceremonies and modes of worship which are regarded as integral parts of religion, and these forms and observances might extend even to matters of food and dress (The Commissioner, Hindu Religious Endowments 1954:1024).

Thus, religious freedom actually extends beyond the individual's conscience and concerns public space through the freedom accorded to religious practice, as stated clearly in Article 25 (1) of the Constitution, quoted above, however limited it may be by considerations of "public order, morality, and health" (a provision common to secular Constitutions throughout the world). ${ }^{6}$ Religious communities are also recognized as such in Article 26 of the Constitution under the label "religious denomination." While the law therefore acknowledges absolute religious freedom in the intimacy of individuals, it also recognizes the fact that the expression of this religious freedom may take various public forms, whether through religious practice or by taking part in religious collectivities and institutions. Nevertheless, this remains an individualistic perspective according to which society - and religion-are made up of an addition of persons, with their rights and actions limited by the public good, a presupposition that is widely at variance from what social science has reported about the entanglement, if not the indeterminacy, of religious issues with social, economic, legal, and political relationships.

More specifically with regard to Hinduism, equality for all citizens, as posited by the Constitution, contradicts views of human nature that are found in many Hindu (upper caste) traditions, which Coward (2005) summarizes as "presuppositions of karma and guna theory." As the author develops, "the very idea of ordering society in terms of sattvic purity of guna theory is ruled out by the new Constitution. It is for this reason that D.E. Smith describes the Constitution as introducing a revolution in traditional conceptions" (Coward 2005:60). ${ }^{7}$ For Coward, the inspiration behind this "revolution" is to be traced back to philosophers such as the Utilitarians (Bentham, Mill) and Locke: "in the Hindu case the Constitution is acting to secularize and reform religion by replacing the karma and guna presuppositions with the Lockean view of human nature" (Coward 2005:64). Even if the "karma and guna theory" might not actually characterize all the traditions that fall under the umbrella of "Hinduism," it is certainly the case that the Constitutional framework-its fundamental assumptions about the individual and about equalityprofoundly re-orientates the perspectives of many religions in India, and imposes a legal universe of discourse which is at variance with widespread conceptions of the position of man and other creatures within an overall divine order.

6 The distinction between private and public domains has had other important consequences in matters of religion: the dissociation of religion, as a private belief and activity, from religious institutions, many of which are deemed public in character, has 
allowed the State since British times to extend its control over these institutions in the name of "rationalizing" their management. ${ }^{8}$ This is made clear in Article 25 (2) (a) of the Constitution:

(2) Nothing in this article shall affect the operation of any existing law or prevent the State from making any law-

(a) Regulating or restricting any economic, financial, political or other secular activity which may be associated with religious practice-my emphasis)

(Constitution of India 1950:article 25(2)(a))

This formulation presupposes the possibility of distinguishing between the "secular" and the "religious," which the Constitution does not define however. It has historically fallen on the Courts to establish, case by case, the activities or situations that were to be considered "secular"-on which they could pass a judgment-and those that were "religious"-outside their jurisdiction (save some exceptions, as we shall see). They rapidly acknowledged that it could not be easily done. As Justice Gajendragadkar wrote in 1963 about Hinduism:

It is true that the decision regarding the question as to whether a certain practice is a religious practice or not, as well as the question as to whether an affair in question is an affair in matters of religion or not, may present difficulties because sometimes practices, religious and secular, are inextricably mixed up. This is more particularly so in regard to Hindu religion because as is well known, under the provisions of ancient Smritis, all human actions from birth to death and most of the individual actions from day to day are regarded as religious in character. ... Though the task of disengaging the secular from the religious may not be easy, it must nevertheless be attempted' (Tilkayat Shri Govindlalji 1963:622).

Justice Gajendragadkar was a judge known for his reformist views who was brought up in a family of pandits and was a Sanskrit scholar versed in Vedanta (Gadbois 2011:71). When he was Chief Justice of India (1964-1966), he put forward in another judgment ${ }^{9}$ a rather encompassing view of Hinduism mostly based on the philosophy of Sarvepalli Radhakrishnan (who was President of India at the time). ${ }^{10}$ While, according to him, establishing "the distinctive features of Hindu religion" was a near impossible task, he nevertheless found that "monistic idealism ... can be said to be the general distinguishing feature of Hindu Philosophy" (a disputable contention) and that however diverse Hindu philosophers and thinkers were, they all "accepted the Vedas as the sole foundation of the Hindu philosophy" (Sastri Yagnapurushadji 1966:262). He added:

Whilst we are dealing with this broad and comprehensive aspect of Hindu religion, it may be permissible to enquire what, according to this religion, is the ultimate goal of humanity? It is the release and freedom from the unceasing cycle of births and rebirths; Moksha or Nirvana, which is the ultimate aim of Hindu religion and philosophy, represents the state of absolute absorption and assimilation of the individual soul with the infinite (Sastri Yagnapurushadji 1966:264)

As many studies have pointed out, this type of idealistic characterization of Hinduism has been at the core of most judgments that have sought to distinguish the (truly) "religious" from the "secular," leading to a complete legal filtering of actual practices.

\section{Winnowing out the chaff}

7 The courts had to define the legal boundary between the religious and the secular through successive rulings, a boundary which became both clear-cut and yet forever shifting as the corresponding case law developed. This was done in various domains. By way of an illustration, I shall sum up here the examples of litigations concerning priestly services in temples. ${ }^{11}$ 
8 As a result of administrative changes that public and private temple management committees have implemented throughout India, the role, position, rights, and appointment of priests and other temple attendants have regularly come before the judges. For instance in a case concerning the hereditary succession to priestly office in some temples in Tamil Nadu, the Supreme Court held that:

the appointment of an Archaka [temple priest] is a secular act and the fact that in some temples the hereditary principle was followed in making the appointment would not make the successive appointments anything but secular. ... That after his appointment the Archaka performs worship is no ground for holding that the appointment is either a religious Practice or a matter of religion (Seshammal 1972:832). ${ }^{12}$

This position was confirmed in other judgments. The notion of "secular," as far as priests were concerned, was also expanded. While in the previous judgment it was the appointment of a priest that was deemed to be secular, in a subsequent one the Supreme Court held that it was the service of the priest as well as his person which were secular:

There is a distinction between religious service and the person who performs the service; performance of the religious service ... is an integral part of the religious faith and belief .... But the service of the priest (archaka) is a secular part. ... Though performance of the ritual ceremonies is an integral part of the religion, the person who performs it or associates himself with performance of ritual ceremonies, is not (A.S. Narayana Deekshitulu 1996:118). ${ }^{13}$

As previously mentioned, this legal view of priesthood largely departs from former Hindu conceptions of the person and especially from the religious qualifications required for performing temple service. This led to a decision taken by the Supreme Court in 2002 that opened priesthood in public temples (including Brahmanical ones) to all castes. ${ }^{14}$

The disentanglement of the religious and the secular which is thus undertaken by the courts also makes use of a very powerful legal tool already present in other Common Law systems, that of "essential practices." 15 It is worth noting that the notion has evolved markedly in the Indian context and, from being applied to the secular domain, opened the possibility of the courts' intervention in the religious realm. For instance in 1954, in the so called Shirur Mutt case, already mentioned, Justice Mukherjea equated nonessential practices with "secular activity":

[religion] should be taken in its strict etymological sense as distinguished from any kind of secular activity which may be connected in some way with religion on but does not form an essential part of it (The Commissioner, Hindu Religious Endowments 1954:1018)

However, in 1961, another decision by Justice Gajendragadkar, who was an open advocate of religious reform and for whom the notion of an essential practice applied not only to secular practices but to religious ones, marked a turning point (Dhavan and Nariman 2000:260):

[I]t may not be out of place incidentally to strike a note of caution and Observe that in order that the practices in question should be treated as a part of religion they must be regarded by the said religion as its essential and integral part; otherwise even purely secular practices which are not an essential or an integral part of religion are apt to be clothed with a religious form and may make a claim for being treated as religious practices within the meaning of Art. 26. Similarly, even practices though religious may have sprung from merely superstitious beliefs and may in that sense be extraneous and unessential accretions to religion itself. Unless such practices are found to constitute an essential and integral part of a religion their claim for the protection under Art. 26 may have to be carefully scrutinised; in 
other words, the protection must be confined to such religious practices as are an essential and an integral part of it and no other.' (The Durgah Committee 1961:412)

It is thus the task of the courts to ascertain what is "essential and integral" in a religion according to its own tenets, and, even if religious, what is not essential (and can be interfered with). The courts' appreciation has been wide-ranging, dealing with questions such as the recipe for an offering, the rules for the consecration of temples, the identity of divine representations, animal sacrifice, etc. Although different judges may hold different opinions, most of them in the upper courts tend to view religion from an idealist perspective-much as Justice Gajendragadkar did. In this, the role of written texts, mostly in Sanskrit and of a normative character, is of major importance: besides satisfying the bent of mind of an elite milieu it meets a legal requirement, that of providing "proof," admissible evidence. Ascertaining what is "essential" to a religious denomination "according to its own tenets" therefore usually means scrutinizing its normative texts; ${ }^{16}$ and the absence of a textual reference for a religious practice or right, without being invalidating, is clearly seen as an obstacle. ${ }^{17}$ A consequence of this predominantly textual vision of religion has been to regard non-essential religious practices as "superstitions." As Bharati (1970) has shown, branding as a superstitious practice has a powerful political and reformist impact in the Indian context. In fact, the legal category of "essential practice" has enabled courts to identify what (according to them) is "superstitious" in Hinduism, "non-essential" and therefore amenable to the courts' reformist action.

Indeed, the Constitution imposes on the State the duty of "providing for social welfare and reform or the throwing open of Hindu religious institutions of a public character to all classes and sections of Hindus" (Constitution of India 1950:Article 25 (2)(b)). As a consequence, religious freedom is subject to other fundamental rights: "No religious right can, therefore, be claimed in contravention of the other fundamental rights." ${ }^{18}$ As $\mathrm{N}$. Bhagwati, Chief Justice of India from 1985 to 1986, stressed, "it was necessary to bring about social reforms with a view to lifting India out of medievalism, obscurantism, blind superstition and anti-social practices" (Bhagwati 2005:43). For this, "the secular State had to perform this historic function of confining religion to its essential sphere," and "the Indian Constitution had, therefore, to accord to the state power to interfere with freedom of religion" (Bhagwati 2005:43). ${ }^{19}$

Though this endeavor is rooted in a secularist agenda, it sometimes seems to converge with the vision developed by Hindu reformist movements in the nineteenth century (Brahmo Samaj, Arya Samaj), which projected an ideal of Vedic purity free of alleged later "superstitions." As Sen argued,

though the impetus for the court's rationalization and homogenization of religion has its origins in a liberal-democratic conception of secularism and the nationstate, as exemplified by India's first prime minister, Jawaharlal Nehru, and philosopher-President Sarvepalli Radhakrishnan, there is a significant overlap between the judicial discourse and the ontology of Hindu nationalism (Sen 2007:6-7)

Indeed, the author points out that there is a possible shift between an inclusivist vision of Hinduism exemplified by Swami Vivekananda or Sarvepalli Radhakrishnan and expressed in terms of an inbuilt tolerance of Hinduism, which appears-to some-to be similar to secularism, toward a more radical and exclusivist vision promoted by Hindutva. ${ }^{20}$ 


\section{Beyond policies: effects of a legal grid}

\section{Legal definitions and their impact}

12 It is important to note that, beyond the personal opinions of individual judges or their will to act as reformers in the name of progress, it is the very nature of the legal process to categorize the world according to its own requirements. For instance, in their quest for precision and "rationality," legal scholars and judges have endeavored to establish a reference language that would be used by all the courts. As part of this process, there is a need to provide unambiguous definitions of common-language expressions that otherwise seem fuzzy or polysemic. It is one of the roles of the Courts to set down these definitions and to establish the legal categories on which judgments may be based, therefore directly impacting the issues in question-in this case, religious life. This intervention of the Courts is systemic in character. It does not necessarily stem from any agenda other than the wish to eliminate semantic indeterminacy or confusion, as can be seen in the fact that today's courts may refer to British colonial precedents or to current Common law in other countries, and that the definitions they articulate may apply indiscriminately to Hinduism, Islam or Christianity. Here are a few examples concerning Hinduism.

One example is the notion of "worshipper." Defining who is to be considered a worshipper was found necessary with regard to the legal requirement of having locus standi, that is, the need to have a personal interest in a given conflict in order to be allowed to file a litigation (this requirement is eschewed in the much less common Public Interest Litigation procedure). In order to accept a petition, a court has to determine if the petitioner has an interest in the case; if not, the petition is rejected. What does it mean to "have an interest" as far as religious matters are concerned? In the case of temples in Tamil Nadu, for instance, Section 6 (15b) of the Tamil Nadu Hindu Religious and Charitable Endowments Act, 1959, explains that it is "a person who is entitled to attend at or is in the habit of attending the performance of worship or service in the temple, or who is entitled to partake or is in the habit of partaking in the benefit of the distribution of gifts thereat" (quoted in Chockalingam 2010:\$33). Thus, only worshippers at a given temple may petition a court about matters regarding this temple. This may indeed sound restrictive. However the notion was given a wide berth by the Madras High Court in 2010 on the basis of a law textbook:

Learned counsel for the first defendant ... submitted that the plaintiffs are not the worshippers and they have no locus-standi to file the suit, and hence, it is worthwhile to refer the book titled, "V.K. Varadachari's Law of Hindu Religious and Charitable Endowments," Revised by Dr. R. Prakash, Advocate, Supreme Court, Fourth Edition 2005, ... which is relied on by the learned counsel for the plaintiffs, in which, it is noted by the renowned author with regard to the meaning of "worshipper" in page 565, as follows: "The word worshipper does not mean only those persons who engage themselves in some sort of rituals for performing worship. It has a wide meaning. Thus, a person merely visiting some temple and after paying his respects goes away, is also a worshipper. A pujari, devotee, archaka, sewak, person coming to have darshan and pay respect are all included in "worshipper." Even a single annual visit is sufficient to make one as worshipper of a particular deity. A person may not have even gone to some temple, even then if he is devoted to that particular one, he will be a worshipper (Chockalingam 2010:\$31). 
As a consequence, such an apparently "technical" definition actually allows almost any person recognized as Hindu and claiming to be a worshipper to have locus standi in a local temple's dispute, without having ever been to that temple-reinforcing the trend to see Hinduism as a matter of individual choice within a larger, national or international community of Hindus.

Other notions for which the courts sought a clear definition concern "custom" and "usage" since it can be-and has been-argued that an infringement of an established usage or custom is a violation of the freedom of religion as protected by the Constitution when there are no contradicting textual authorities and when it does not go against public order and morality.

"Custom" is usually held by the courts to mean "ancient or of remote antiquity or long established, certain, invariable, uniform and continuous and reasonable and not open to objection on the grounds of public policy or otherwise and not opposed to statute. The custom to be valid must also be obligatory or compulsory in the sense that it must not be in the option of any person whether he would conform to it or not" (Muniandi Kone and Ors. 1981:\$16)-this is a series of requirements that dates back to rulings by the Privy Council in the 1870s. "Custom" and "usage" are more often than not mutually associated in judgments according to standardized formulas such as "established custom and usage," "recognized custom and usage," "ancient custom and usage." However the courts have sometimes felt the necessity to make a distinction:

"Usage" and "custom" are words of cognate expression, but nevertheless both have some different perceptions and nuances. The word "usage" generally denotes a habit or a mode of conduct or a course of action. ... In Black's Law Dictionary, the word "usage" is described as different from custom as there is no usage through inheritance though a right can be acquired by prescription. The following passage is worthy of extraction here: "Usage in its most extensive meaning, includes both custom and prescription, but in its narrower significance, it refers to a general habit, mode or course of procedure. A usage differs from a custom, in that it does not require to be immemorial to establish the same, but the usage must be known, certain, uniform, reasonable and not contrary to law" (N. Adithayan 1995:§9).

The consequence of such a distinction is that "usage" has sometimes been seen as imposing much fewer legal constraints in litigation than "custom," since it was felt that there was no need to establish its antiquity:

In Venkataramaiya's Law Lexicon and Legal Maxims, "usage" is defined as one regularly and ordinarily practised by the inhabitants of the place. According to him it is not necessary to require proof of its existence for any length of time in order to establish "usage." The word "usage" would include what the people are now or recently in the habit of doing in a particular place. He would further state that this particular habit may be only of a very recent origin or it may be one which has existed for a long time (S. Mahendran 1991:\$37).

In practice, the ambiguity maintained between "custom" and "usage" and the elasticity given to the latter have enabled courts to develop interpretations that may seem to deviate from the constitutional recognition of custom or usage as instances of "law," opposing for example usage or custom to established rights, or to rituals founded on a textual authority, and holding that a custom is not inviolable and may need to change with the times. Indeed, as Breckenridge (1977) or more recently Das Acevedo (2016) have shown, courts themselves may establish and create a custom or a usage.

Not all definitions reached by the courts are so permissive. For instance, the Supreme Court ruled in 1997 that a "religious ceremony" ends as soon as offerings are made; thus 
the act of collecting offerings after this was not part of a religious duty; it was distinct and secular in character (State of Orissa And Sri Jagannath 1997). The understanding of what a "religious service" is was thus considerably restricted compared to ordinary and widespread Hindu practices, conversely extending the scope of the "secular" domain that is open to control by temple management.

There are many other instances of how imposing legal boundaries on religious categories directly affects the way litigations may be decided. A "religious office" has been defined in the same contractual terms as any commercial or administrative office, thereby injecting into the religious domain legal concepts defined for other contexts and purposes:

It is clear that, to constitute an office one, if not the essential, thing is the existence of a duty or duties attached to the office which the office-holder is under a legal obligation to perform and the nonperformance of which may be visited by penalties, such as a suspension, dismissal, etc (Vathiar Venkatachariar 1918).

This definition was relied upon in a Supreme Court judgment in 1961 regarding whether a South Indian religious pontiff had an "office" in this legal sense in a particular temple, where he claimed precedence for receiving customary honors. The Court also ruled that these honors were not part of any office (in this legal sense) and could not therefore be considered as legal rights: in order for honors to fall under the jurisdiction of the courts, they need to be "an integral part of the ritual to be performed" and "a part of the remuneration to the office"-my emphasis) (Sri Sinna Ramanuja Jeer And Others 1961). What is paradoxical is that in deciding courts had no jurisdiction over these religious honors, the Supreme Court actually developed at length notions at the core of temple life with an immediate effect on the relationships between temple devotees and the authorities. What is a religious office? It is a contractual service that can be subjected to penalties. What is a religious honor? The Supreme Court supported an idea formulated by J. Sadasiva Aiyar in 1913 according to which it is a divine favor that one should be ashamed to claim as a "right."(Athan Sadagopachariar Swamigal 1913) As a consequence, litigations concerning honors that were not part of the "remuneration of an office" could not be accepted by civil courts: by disclaiming any jurisdiction on such matters and apparently protecting the freedom of religion, the Supreme Court actually enforced a very restricted understanding of "religious honors" with far-reaching consequences for religious practices and claims.

\section{A question of jurisdiction}

However, there are situations recognized by the courts as religious ones but over which they nevertheless have jurisdiction. This is made possible by considering that conflicts involving certain religious issues pertain to questions of civil rights, which are to be decided by civil courts of law.

For instance, the right to religious office is "in the nature of property under the Hindu Law" (Raj Kali Kuer 1955:189), ${ }^{21}$ a good example of how a legal concept from a different context (here property laws) is extended to religion; therefore civil courts have full jurisdiction to decide on this matter. The Code of Civil Procedure (Section 9, Explanation I) is very explicit about this and adds that "a suit in which the right to property or to an office is contested is a suit of a civil nature, notwithstanding that such right may depend entirely on the decision of questions as to religious rites or ceremonies"-my emphasis) 
Similarly, the right to worship in a specific place (e.g. a temple) has been treated as a "right to access land and water," and is protected under Sections 145 and 147 of the Criminal Procedure Code. These sections enable an Executive Magistrate to act whenever a dispute concerning such a right is "likely to cause a breach of peace." Since the expression "land and water" is said to cover "buildings, markets, fisheries, crops or other produce of land, and the rents of any such property," it also applies to temples, and more largely to places of worship. By extension, it actually protects the right to worship (in a particular place):

The dispute as to worship, however, may be a dispute as to the worship of a deity in a particular temple or place. It appears to me that if such be the dispute then the dispute as to the worship necessarily involves a dispute as to the user of the land or building in which the particular deity is located.... To deny the right of worship in a particular place is to deny the right to use that place in a particular manner. The right to worship as I have said cannot be regarded as something entirely apart from the place of worship ... it must be held that a dispute as to the right to worship a deity in a particular temple is a Dispute falling within the ambit of Section 147, Cr. P. C. (Dhirendra Nath Das 1951:\$38).

Madras High Court already held that the right of an individual to worship in a temple can be assimilated to the general category of "right to access land":

It may be that the dispute in actual fact may have more to do with what a man does in the temple after entering into it and not so much with his actual entry into the temple; nevertheless where the right regarding which a dispute exists is one which is inseparably connected with the right to enter a building and cannot be dissociated from it the dispute cannot be said to be not one regarding an alleged right of user of the building (Velappa Goundan And Ors. 1938, quoted in Chinnubhai Chandulal Parikh 1971:\$5)

Indeed, the right to worship is so firmly established that courts do not necessarily refer to a right to "access to land and water" in this respect, and consider it to be simply a civil right in itself-it has been affirmed that "the right to an act of worship stands on the same footing as a right to an office; a person is entitled to enforce it by suit in the same way" (Thirumalai Alwar Aiyangar 1916:\$18).

21 A conflict among Jains provides an illustration of the kind of decision on rituals that courts take in order to protect the right to worship. In Ugamsingh \& Mishrimal (1970) decided by the Supreme Court, Digambaras were opposed to Svetambaras putting false eyes (chaksus) on an idol of the first Tirthankara (Rishabhanatha / Adinatha) in a temple at Paroli (Rajasthan) that both sects shared, and adding a flag mast (dvajadand) and a crowning kalash to the temple. Neither these additions to the temple nor the attributes added to the idol were acceptable to the Digambaras-e.g. they could only worship an idol of a Tirthankara if it were left naked.

The Digambaras complained that the Svetambaras "attempted to convert the said idol into the idol of Swetambara Sect by putting Chakshus (artificial eyes) thereon, but were prevented from doing so by a strong opposition of the followers of the Digamber Sect"; that they (the Svetambaras) planned "to put Dhwajadand and Kalash on the said Temple according to their tenets"; and that they intended "to enclose the said idol by putting up doors and locks with the object of interfering with and obstructing the free exercise by the Digamberies of their unfettered rights to perform Poojan, Prakshal and worship of the said idol according to their tenets." (Ugamsingh \& Mishrimal 1970:\$3).

As for the Swetambaras, they objected in the course of various arguments that "the Civil court had no jurisdiction to decide the religious rights of the parties nor is it a dispute of 
the civil nature" (Ugamsingh \& Mishrimal 1970:\$4). However, the Supreme Court considered that the moves contemplated by the Swetambaras "could preclude the Digamberies from worshipping in accordance with their tenets" (Ugamsingh \& Mishrimal 1970:\$15):

It is admitted that the Digamberies will not worship the idol which is not "Nirakar" ["shapeless"] or which has Chakshus. If the Digamberies have a right to worship at the temple the attempt of the Swetamberies to put Chakshus to place Dhwajadand or Kalash in accordance with their tenets and to claim that the idol is a Swetamberi idol was to preclude the Digamberies from exercising their right to worship at the temple. These findings clearly establish that the Appellants interfered with the rights of Digamberies to worship with respect to which a civil suit is maintainable under section 9 of the Civil Procedure Code. (Ugamsingh \& Mishrimal 1970:\$15)

After establishing that the Digambaras had a traditional right to worship in the temple, the Court therefore ruled that putting chakshus and making other additions to the idol and to the temple would prevent Digambaras from worshipping: therefore their civil "right to worship" was threatened, and the courts had full jurisdiction to intervene-in that case, by forbidding the Svetambaras from making their contested additions. Though the basic principle according to which the courts will not endeavor to lay down a ritual which is to be followed in the worship is constantly reiterated, the consequence of the courts' jurisdiction over rights to worship or access a religious office-which are civil rights-has therefore actually led to many interventions in ritual matters, which has indeed been made plain:

Disputes pertaining to religious office including performance of rituals were always decided by the Courts established by law. There are numerous authorities where dispute about entry in the Temple, right to worship, performing certain rituals, have been taken cognizance of and decided by civil Courts. The Court protects persons in the enjoyment of a certain status or property and it may incidentally become the duty of the Civil Court to determine what are the accepted tenets of the followers of a creed and what is the usage they have accepted as established for the regulation of their rights inter-se' (Chockalingam 2010:\$34-my emphasis). ${ }^{22}$

\section{Striking a balance between the right to worship and ways of worshipping}

Courts protect the right to worship as a civil right and the freedom to do so according to one's own belief; however, such worship should not affect the right of other persons and has to be bona fide. Two brief examples illustrate the impact the courts' assessment of this condition may have.

The Punjab and Haryana High Court in Rattan Singh and ors. (1951) had to deal with a conflict between bareheaded devotees and covered-headed ones in a mandir which Lahore High Court had previously (1936) declared not to be a Sikh Gurdwara. Bareheaded devotees complained they were prevented by the covered-headed ones from entering the mandir and worshipping there. The High Court, quoting precedents, underlined the general principle according to which the right to worship a deity according to one's own belief is of a civil nature. The judge decided in favor of the plaintiffs because, according to him, coming bareheaded could not be seen as affecting others' right to worship: "whether a man goes bare-headed or otherwise is not a form of ritual and even if he goes into the temple and begins to worship without anything on his head it may be good or bad manners according to the notions of the people but this has no reference to the ritual" ( Rattan Singh and ors. 1951:§5). 
This power of the courts does not concern Hinduism alone-which reinforces the idea that this form of legal action in religious matters is beyond any particularities regarding policies or persons. For instance, Allahabad High Court ruled in Syed Farzand Ali (1980) that Muslims of the Ahl-i-Hadith tradition had the right to speak the word "Amen" aloud in response to the prayer leader in mosques of the Mathura district without being hindered by Muslims of the Hanafi tradition who tried to oppose this practice. This was a long-standing conflict and judgments to decide the same question already existed by the end of the nineteenth century (Queen Empress 1885; Ataullah 1890). These earlier rulings were confirmed by the Allahabad High Court, with particular reference to Justice Mahmood in Ataullah:

As to the question of pronouncing the word "Aameen" I hold that the word "Aameen" must be said at the end of the prayer ending with Sure-i-Fateha. I hold also that this should be pronounced. I hold also that there is a difference of the exact note in which it should be pronounced and I hold that there is no authority to say at what note of the vocal octave the voice should emanate. There are some who think that the speaking of the word "Aameen" aloud is required by devotion and feeling and is necessary for their prayers. I hold, therefore, that there is no authority in the Mohammadan Ecclesiastical Law to limit the tone of voice in which the word "Aameen" is to be pronounced; that so long as the plaintiffs appellants are Muhammadans, as we have found they are, so long they are entitled to enter the mosque and perform the worship and say the word "Aameen" without anything to restrain their tone or note of the octave. But if the pronouncement of the word "Aameen" results in the disturbance of peace, that of course will have to be dealt with under the Criminal Law. (quoted in Syed Farzand Ali 1980:\$5)

Indeed, the margin between legitimately deciding on religious issues (when civil rights are deemed to be at stake) and unduly interfering in religious matters is rather narrow. As was stressed in Gopanna, "it may not always be easy to draw the line between what is merely a part of the ritual of worship and what is a right to conduct the worship itself" ( $J$. Gopanna 1944). The above judgment in Syed Farzand Ali (1980) was thus commented upon and implicitly disagreed with in another case, this time concerning Christians (Koil Pillai):

a careful reading of the decision would indicate that it is only an authority for the proposition that Mussalman is entitled to enter a mosque which is dedicated to God and is also entitled to join in the prayers and utter the word "Aameen" loudly but not with the aim or mala fide intention to disturb the peace of the congregation. Besides the single Judge of the Allahabad High Court who rendered the decision has not given any reason for holding that the utterance of the word "Aameen" is not a ritual or a form of prayer but a civil right (Koil Pillai 1992:\$8). ${ }^{23}$

In this case the judge instead stressed the line of argument previously developed in M. Appadorai Aiyangar to strike a balance between the two contradictory requirements made of the courts: not to interfere in religious matters while protecting civil rights, which may lead to such interference.

It has been recognised that the Court in adjudicating on a right of worship or a right to a religious office not infrequently is obliged to decide incidentally questions of ritual but it follows that the Court will not on a mere pretence that a right to worship has been infringed, arrogate to itself a jurisdiction which it does not possess to prescribe forms of prayer, rights to religious precedence and questions of that nature. (M. Appadorai Aiyangar 1938:\$11)

\section{Final remarks}

Discussing secularism in India is usually done by analyzing the Constitutional provisions and the acts of judges in their implementation. As the first part of this paper recalls, 
extended scholarship has underlined the growth and the importance of legal categories such as "secular," "essential practices," "superstition," in shaping Hinduism today. The reformist agenda promoted by some judges in accordance with an interpretation of the Constitution that gives precedence to fundamental rights over the protection of religious freedom has further widened the scope of the law's intervention. However, important changes in religion are also brought forth through action of a less political nature on the part of the courts. Such processes result from systemic properties of Common law and are quite independent from any secularist agenda. One of them, already identified by scholars, is the general effect produced by the fact that the Constitution is centered on individuals on the basis of equality, a legal framework at odds with widely shared Hindu conceptions and practices. The second part of this paper has tried to explore two other characteristics of the legal system that may similarly have a quasi-mechanical impact on religion (not only Hinduism but others as well): the fact that ordinary words are given a legal, technical definition that is sometimes quite different from their usual understanding in the religious realm (for instance "religious service," "religious office," "religious honor"); and the fact that the protection of a civil right such as the "right to worship" imposes on the court the duty to rule on related religious issues, even "essential" ones.

As a matter of fact, many of these legal definitions and the whole reasoning behind the discussion on jurisdiction make use of notions that were originally developed for other purposes. A right to an office is taken as an instance of a more general right to property. The right to a religious office does not differ from the right to any other office, which means that it must satisfy the same conditions to be held valid. The right to worship is taken as just one instance of the right to access or use land and water, which is regulated by dispositions of the Criminal Code.

This suggests a much deeper-rooted entanglement of law and religion than is usually assumed. At one level it certainly can be approached in terms of heritage, or enforcement of secularism, or religious reform, or a judge's personal agenda. But at a much more fundamental level it also results from the legal system itself which imposes a legal categorization on aspects of religious life: religion has to fall within this legal universe of discourse and of enforceable rules. The kind of religion that is thus eventually shaped is mostly framed by questions and rules that were initially elaborated for other, nonreligious litigations. Indeed, nearly all aspects of religious life may thus be re-defined through such legal categories projected and imposed on religious issues, a fact often underestimated in the description of actual attitudes, practices, and institutions in religion.

\title{
BIBLIOGRAPHY
}

\author{
1. Judgments and Acts
}


A.S. Narayana Deekshitulu v. State of Andhra Pradesh, Supreme Court of India, on 19 March 1996 [1996 III AD (SC)135, AIR1996SC1765, JT1996(3)SC482, 1996(2)SCALE911, (1996)9SCC548, (1996)3SCR543]

Adi Saiva Sivachariyargal ... v. Govt. Of Tamil Nadu \& Anr, High Court of Madras, on 16 December 2015 [W.P. (C) 354 OF 2006,355 of 2006,383 of 2006 , and 384 of 2006]

Ataullah v. Azim Ullah, (1890) ILR 12 All 494.

Athan Sadagopachariar Swamigal v. Elayavalli Srinivasachariar, (1913) M.W.N. 289.

Chinnubhai Chandulal Parikh And ... v. Dhanyakumar Motiram Belokar And ..., Bombay High Court, on 2 March 1971 [1971 CriLJ 1597]

Chockalingam (Now Died) v. Nambi Pandiyan, Madurai Bench of Madras High Court, on 29 November 2010

Code of Civil Procedure of 1908 (The). 2002.

Code of Criminal Procedure of 1973 (The). 2014.

Constitution of India of 1950 (The). 2015.

Dhirendra Nath Das v. Hrishikesh Mukherjee And Ors., Calcutta High Court, on 20 March 1951 [AIR 1951 Cal 93, 55 CWN 594].

J. Gopanna v. K. Ramaswami, on Feb-04-1944, AIR1944Mad416.

K. Seshadri Aiyangar and two Ors. v. Ranga Bhattar, Madras High Court, on 7 April 1911 [(1912) ILR35Mad631].

Kodakkattu Cheriya Krishnan Namboothiri v. The Guruvayoor Devaswom, Kerala High Court, on 25 November 2008 [2009 (1) KLT 506]

Koil Pillai v. Territorial Command or Territorial Head Quarters, Salvation Army and Other, on 20 November 1992, AIR1994Mad27; (1993)IIMLJ117.

Krishname \& Ors. v. Krishnasamy \& Ors., Madras High Court [1879 ILR 2 Mad.]

M. Appadorai Aiyangar (Deceased) ... v. P.B. Annangarachariar And Ors., on 13 September 1938, AIR 1939 Mad 102; (1939) 1 MLJ 124

Mitta Kunth Audhicarry v. Neerunjun Audhicarry, 1874 [(1875) XIV B.L.R. 166; 22 W.R. 437]

Most. Rev. P.M.A. Metropolitan \& ... v. Moran Mar Marthoma \& Anr, Supreme Court of India, on 20 June 1995 [1995 AIR 2001, 1995 SCC Supl. (4) 286, JT1995(5)SC1, 1995(4)SCALE1, [1995]Supp1SCR542].

Muniandi Kone and Ors. v. Sri Ramanatha Sethupathi, Hereditary Trustee of Arulmigu Mangalanathaswami Temple and Anr., Chennai High Court, on 6 July 1981 [AIR1982Mad170; (1982)1MLJ20]

N. Adithayan v. The Travancore Devaswom Board And Ors., Kerala High Court, on 4 December 1995 [AIR 1996 Ker 169]

N. Adithayan v. The Travancore Devaswom Board \& Ors., Supreme Court of India, 3 October 2002 [AIR 2002 SC 3538, 2003(1)ALD28(SC), 2002(4)ALLMR(SC)843, 95(2003)CLT504(SC), JT2002(8)SC51, 2002 (3)KLT615(SC), (2002)8SCC106, [2002]SUPP3SCR76]

Queen Empress v. Ramzan And Ors., on 7 March 1885 (1885) ILR 7 All 461;

Raj Kali Kuer v. Ram Rattan Pandey, Supreme Court of India, on 7 April 1955 [1955 AIR 493, 1955 SCR (2) 186] 
Ratilal Panachand Gandhi v. State Of Bombay, Bombay High Court, on 12 September 1952 [AIR 1953 Bom 242, (1953) 55 BOMLR 86, ILR 1953 Bom 1187]

Rattan Singh and ors. v. Beli Ram and ors., on 6 July 1951, AIR1952P\& H163.

S. Mahendran v. The Secretary, Travancore ..., Kerala High Court, on 5 April 1991 [AIR 1993 Ker 42] Sastri Yagnapurushadji And ... v. Muldas Brudardas Vaishya And ..., Supreme Court of India, on 14 January 1966 [1966 AIR 1119, 1966 SCR (3) 242]

Seshammal \& Ors, etc. etc v. State Of Tamil Nadu, Supreme Court of India, on 14 March 1972, p.832 [AIR 1972 SC 1586, (1972) 2 SCC 11, (1972) 3 SCR 815].

“Shirur Mutt," see The Commissioner, Hindu Religious Endowments

Sri Sinna Ramanuja Jeer And Others v. Sri Ranga Ramanuja Jeer And ... on 27 April 1961, 1961 AIR 1720, 1962 SCR (2) 509.

State of Orissa And Sri Jagannath ... v. Chintamani Khuntia and Ors, Supreme Court of India, on 17 September 1997 [CA No. 3979 of 1995]

Syed Farzand Ali v. Nasir Beg And Ors., on 28 February 1980, AIR 1980 All 342.

Tamil Nadu Hindu Religious and Charitable Endowments Act of 1959 (The). 2013.

The Commissioner, Hindu Religious Endowments v. Sree Lakshmindra Tirtha Swaminar of Sri Shirur Mutt, Supreme Court of India, on 16 April 1954 [1954 AIR 282, 1954 SCR 1005]

The Durgah Committee, Ajmer and Anr. v. Syed Hussain Ali and Ors., Supreme Court of India, on 17 March 1961 [(1962) 1 SCR 383 at 411-412]

Thirumalai Alwar Aiyangar ... v. Lakshmi Sadagopa Aiyangar And ..., on 24 August 1916, AIR 1917 Mad 903; 36 Ind Cas 568; (1916) 31 MLJ 758.

Tilkayat Shri Govindlalji ... v. The State Of Rajasthan And Others, Supreme Court of India, on 21 January 1963 [1963 AIR 1638, 1964 SCR (1) 561]

Ugamsingh \& Mishrimal v. Kesrimal \& Ors, Supreme Court of India, on 26 November 1970 [1971 AIR 2540, 1971 SCR (2) 836]

Vathiar Venkatachariar v. P. Ponappa Ayyangar, (1918) 45 I.C. 959.

Velappa Goundan And Ors. v. Ramaswami Goundan And Ors., on 24 January 1938, AIR 1938 Mad 537; (1938) 1 MLJ 817.

\section{Bibliography}

Agrama, Hussein Ali. 2010. "Secularism, Sovereignty, Indeterminacy: Is Egypt a Secular or a Religious State?" Comparative Studies in Society and History 52(3):1-29.

Baird, Robert D. [1993] 2005. “On Defining 'Hinduism' as a Religious and a Legal Category." Pp. 69-86 in Religion and Law in Independent India, edited by R.D. Baird. $2^{\text {nd }}$ enlarged edition. New Delhi: Manohar.

Baltutis, Michael C. [1993] 2005. "Recognition and Legislation of Private Religious Endowments in Indian Law." Pp. 443-47 in Religion and Law in Independent India, edited by R.D. Baird. $2^{\text {nd }}$ enlarged edition. New Delhi: Manohar.

Baxi, Upendra. 2007. "Commentary: Savarkar and the Supreme Court." Pp. 47-58 in Legalizing Religion: The Indian Supreme Court and Secularism, edited by R. Sen. Washington: East-West Center. 
Berti, Daniela, Gilles Tarabout, and Raphaël Voix, eds. 2016. Filing Religion: State, Hinduism, and Courts of Law. New Delhi: Oxford University Press.

Bhagwati, P.N. [1993] 2005. "Religion and Secularism under the Indian Constitution." Pp. 35-49 in Religion and Law in Independent India, edited by R.D. Baird. $2^{\text {nd }}$ enlarged edition. New Delhi: Manohar.

Bharati, Agehananda. 1970. “The Use of 'Superstition' as an Anti-traditional Device in Urban Hinduism." Contributions to Indian Sociology (ns)IV:36-49.

Breckenridge, Carol Appadurai. 1977 "From Protector to Litigant: Changing Relations Between Hindu Temples and the Rājā of Ramnad." Indian Economic and Social History Review, XIV(I):75-106.

Chiriyankandath, James (1999) “Constitutional Predilections.” Seminar 484:50-55. Retrieved April 19, 2016 (http://www.india-seminar.com/1999/484/484chiriyankandath.htm).

Coward, Harold G. [1993] 2005. "India's Constitution and Traditional Presuppositions Regarding Human Nature." Pp. 51-67 in Religion and Law in Independent India, edited by R.D. Baird. $2^{\text {nd }}$ enlarged edition. New Delhi: Manohar.

Das Acevedo, Deepa. 2016. “Celibate Gods and 'Essential Practices': Jurisprudence at Sabarimala, 1991-2011." Pp. 101-46 in Filing Religion: State, Hinduism, and Courts of Law, edited by D. Berti, G. Tarabout, and R. Voix. New Delhi: Oxford University Press.

De, Rohit. 2013. “The Republic of Writs: Litigious Citizens, Constitutional Law and Everyday Life in India (1947-1964).' PhD dissertation, Princeton University.

Dhavan, Rajeev. 1987. "Religious Freedom in India." The American Journal of Comparative Law 35 (1):209-54.

Dhavan, Rajeev. 2001. “The Road to Xanadu: India's Quest for Secularism.” Pp. 301-29 in Religion and Personal Law in Secular India: A Call to Judgment, edited by G.J. Larson. Bloomington: Indiana University Press.

Dhavan, Rajeev, and Fali S. Nariman. 2000. "The Supreme Court and Group Life: Religious Freedom, Minority Groups, and Disadvantaged Communities." Pp. 256-87 in Supreme but not Infallible: Essays in Honour of the Supreme Court of India, edited by B.N. Kirpal, A.H. Desai, G. Subramanium, R. Dhavan, and R. Ramachandran. New Delhi: Oxford University Press.

Fuller, Christopher J. 1988. "Hinduism and Scriptural Authority in Modern Indian Law." Comparative Studies in Society and History 30(2):225-48.

Fuller, Christopher J. [1984] 1991 Servants of the Goddess: The Priests of a South Indian Temple. NewDelhi: Oxford University Press ( $1^{\text {st }}$ ed. Cambridge University Press).

Fuller, Christopher J. 2003. The Renewal of the Priesthood: Modernity and Traditionalism in a South Indian Temple. Princeton: Princeton University Press.

Gadbois, George H., Jr. 2011. Judges of the Supreme Court of India, 1950-1989. New Delhi: Oxford University Press.

Galanter, Marc .1971. "Hinduism, Secularism, and the India Judiciary." Philosophy East and West 21 (4):467-87.

Halbfass, Wilhem .1988. “'Inclusivism' and 'Tolerance' in the Encounter between India and the West.” Pp. 403-18 in Wilhem Halbfass, India and Europe: An Essay in Philosophical Understanding. $1^{\text {st }}$ German edition 1981. Albany: SUNY Press.

Hatcher, Brian A. 1994 “'The Cosmos is One Family' (vasudhaiva kutumbakam): Problematic Mantra of Hindu Humanism." Contributions to Indian Sociology (ns) 28(1):149-62. 
Jurinski, James John. 2004. Religion on Trial: A Handbook with Cases, Laws, and Documents. Santa Barbara: ABC-CLIO Inc.

Kirsch, Thomas G., and Bertram Turner, eds. 2009. Permutations of Order: Religion and Law as Contested Sovereignties. Farnham: Ashgate.

Lambek, Michael. 2013. “Interminable Disputes in Northwest Madagascar." Pp. 1-18 in Religion in Disputes: Pervasiveness of Religious Normativity in Disputing Processes, edited by F. von BendaBeckmann, K. von Benda-Beckmann, M. Ramstedt, and B. Turner. New York: Palgrave MacMillan. Lariviere, Richard, W. 1989. "Justices and Panditas: Some Ironies in Contemporary Readings of the Hindu Legal Past." Journal of Asian Studies 48(4): 757-69.

Mallampalli, Chandra S. 1995. “Separating 'Religion' from Politics: Denying or Rechanneling India's Past?” Ethnic Studies Report XIII(1):73-111.

Mudaliar, Chandra Y. 1974. The Secular State and Religious Institutions in India: A Study of the Administration of Hindu Public Religious Trusts in Madras. Wiesbaden: Franz Steiner Verlag.

Presler, Franklin A. 1987. Religion under Bureaucracy: Policy and Administration for Hindu Temples in South India. Cambridge: Cambridge University Press.

Reiniche, Marie-Louise. 1989. Tiruvannamalai, un lieu saint śivaïte du sud de l'Inde-4. La configuration sociologique du temple hindou. Paris: EFEO.

Rudolph, Lloyd I., and Susanne Hoeber Rudolph. 1965. "Barristers and Brahmans in India: Legal Cultures and Social Change." Comparative Studies in Society and History 8(1):24-49.

Sen, Ronojoy. 2007. Legalizing Religion: The Indian Supreme Court and Secularism. Washington: EastWest Center.

Sen, Ronojoy. 2010. Articles of Faith: Religion, Secularism and the Indian Supreme Court. New Delhi: Oxford University Press.

Tarabout, Gilles. 2016. "Birth vs. Merit: Kerala Temple Priests and the Courts." Pp. 3-33 in Filing Religion: State, Hinduism, and Courts of Law, edited by D. Berti, G. Tarabout, and R. Voix. New Delhi: Oxford University Press.

Voix, Raphaël. 2016. “The Legal Making of a 'Hindu Sect': Understanding the Tandava Case in its Context." Pp. 149-96 in Filing Religion: State, Hinduism, and Courts of Law, edited by D. Berti, G. Tarabout, and R. Voix. New Delhi: Oxford University Press.

Warrier, Maya. 2003. "Processes of Secularization in Contemporary India: Guru Faith in the Mata Amritanandamayi Mission." Modern Asian Studies 37(1):213-53.

Yamunan, Sruthisagar:2015. "Failing the Test of Gender." The Hindu, December 22. Retrieved April 19, 2016 (http://www.thehindu.com/opinion/op-ed/sruthisagar-yamunan-writes-aboutsupreme-court-ruling-on-priest-appointment-failing-the-test-of-gender/article8014690.ece).

\section{NOTES}

1. See also Kirsch and Turner (2009). As Agrama (2010) argues, the discourse on secularism constantly blurs the distinction it claims to establish between a religious domain and a secular one, and the management of this indeterminacy is at the very root of the state's power as a "secular" political entity.

2. For a discussion, see Baxi (2007). 
3. For a broader study of the role of the State and of Courts of law in the management of Hinduism in India, see Berti, Tarabout and Voix (2016), which is an outcome of the Project "Justice and Governance in Contemporary India and South Asia" ("Just-India," see www.justindia.net), 2009-2012, funded by the French "Agence Nationale de la Recherche" (program ANR-08-GOUV-064). The materials and ideas set forth in the present paper benefited from discussions during a Yale seminar in 2015 and a Yale workshop ("Entanglements of Law and Religion in South Asia," April 28-29, 2017, organized by the South Asian Studies Council at the Yale MacMillan Center). I wish to thank the discussants and the participants for their remarks. I am also grateful to the two anonymous SAMAJ reviewers for their helpful suggestions.

4. I have relied on the reading of more than 200 relevant judgments found on the internet; only a few are referenced here (their full reference is provided at the end of the paper). There might be the feeling that there is an over-representation of judgments coming from South India, which might be due both to historical factors (the early development of temple regulations by the colonial state in the former Madras Presidency) and to personal idiosyncrasies (Kerala is my privileged area of study). All the judgments studied come from the upper courts: this does not mean that subordinate or District and Sessions judges do not deal with religious issues (they do, as traces of their decisions may be found in appeal documents), only that upper courts' judgments are the basis of case law, as well as being more easily available.

5. However De cautions us "against reading the dramatic growth of individual rights claims as a growth in individual rights consciousness" (De 2013:51)

6. As Dhavan comments, the lack of a precise definition of these terms is such that "almost any part of religious activity is subject to control" (Dhavan 1987:230)

7. The reference to D.E. Smith concerns one of his books that was published in 1963, India as a Secular State.

8. See Mudaliar (1974) and Presler (1987) for comprehensive studies of this process in the Madras Presidency. Public endowments, which the state has the duty to regulate, are distinguished from private endowments, which have wide autonomy; however the boundary between the two is not always situated in the same place by the courts or by the legislature (Baltutis 2005). Many scholars have pointed out that there has been an increase in State control over religious endowments since 1950-Dhavan even suggests that "What is happening is not the temporary intervention of regulatory control by the state. Religious endowments are being nationalized on an extensive scale" (Dhavan 2001:315).

9. Sastri Yagnapurushadji 1966. The case concerned the Swaminarayanan sect claiming in appeal to the Supreme Court to be a distinct religion from Hinduism (the appeal was dismissed).

10. Baird (2005) has pointed out that this important judgment blurs the distinction made in the Constitution between Hinduism as a religious category and Hinduism as a legal category.

11. For a detailed case study see Tarabout (2016).

12. Seshammal 1972. For a discussion of this important case, see Fuller (1991, 2003), Presler (1987), Reiniche (1989). British rulings were already quite similar; see for instance K. Seshadri Aiyangar 1911.

13. Similarly, the preparation of food offerings was declared to be a religious process, but the conduct of the person engaged in their preparation could not be said to be religious in any way. Kodakkattu Cheriya Krishnan Namboothiri 2008.

14. N. Adithayan 2002. For a more detailed treatment of this question, see Tarabout 2016. The question is still topical: see more recently Adi Saiva Sivachariyargal 2015; among various critical comments on this latter case, see Yamunan 2015.

15. For a detailed critique, see Dhavan and Nariman (2000:259-61).

16. For example, the question as to whether or not the so-called "tandava dance" was an essential part of Ananda Marga's tenets was discussed in court in terms of (the absence / writing up of) textual reference-see Voix 2016. On the role of pandits self-assumed by judges 
interpreting Sanskrit texts, and acting therefore as religious authorities, see for instance Rudolph and Rudolph (1965), Galanter (1971), Dhavan (1987), Fuller (1988), Lariviere (1988).

17. However ritual normative texts may sometimes be balanced with "established usage"Chockalingam 2010.

18. N. Adithayan 1995:§ 16 .

19. "The wide powers granted to the state in pursuit of the reform of Hindu social practices sharply contrasted with the concern not to be seen as interfering with the religious practices of Muslims or Christians. By associating the Indian state with the reform of the social practices of people belonging to a particular religious tradition, it placed the state in a unique position in relation to that tradition." (Chiriyankandath 1999)

20. The supposedly specific "tolerance" of Hinduism and the political consequences of this assumption have been critically discussed at length. See for instance Halbfass (1988, a comment on Paul Hacker's concept of “Inklusivismus"), Hatcher (1994), Mallampalli (1995), Sen (2010:6-7).

21. This judgments quotes numerous precedents from the 1930s onward. As early as the 1870s, in Mitta Kunth Audhicarry 1874 it was ruled that hereditary priestly office in a family was a "property" subject to partition between joint owners.

22. This is actually a quote from an 1879 judgment: "It is certainly not the duty of the Civil Court to pronounce on the truth of religious tenets nor to regulate religious ceremony; but, in protecting persons in the enjoyment of a certain status or property, it may incidentally become the duty of the Civil Court to determine what are the accepted tenets of the followers of a creed and what is the usage they have accepted as established for the regulation of their rights inter-se" (Krishname \& Ors. 1879), also quoted in Most. Rev. P.M.A. Metropolitan 1995. The latter judgment concludes "it is clear that a suit filed after coming into force of the Constitution for vindication of rights related to worship of status, office or property is maintainable in civil court and it would be [the] duty of the court to decide even purely religious questions if they have a material bearing on the right alleged in the plaint regarding worship, status or office or property."

23. This observation was rather a simplification of Syed Farzand Ali (1980) as the judge in the latter case relied on Ataullah (1890) in which detailed argumentation is provided.

\section{ABSTRACTS}

The Indian Constitution posits a separation between a secular domain regulated by the State, and a religious domain in which it must not interfere. However, courts of law are regularly called upon to resolve a multiplicity of issues related to religion, and their decisions may have a farreaching impact on religious conceptions and practices. The judicial process requires that standardized, clear-cut definitions of many notions (such as "religion" itself, or "worshipper," "custom," "usage," "religious service," "religious office," "religious honor," etc.) be established in order for them to be manageable within a legal context. Moreover, even though a religious domain may be distinguished from a secular one and protected from State intervention, there are litigations concerning civil rights that involve religious issues on which civil courts may therefore have an explicit duty to rule. Interventions such as imposing legal definitions or deciding on religious matters on which civil rights depend are systemic in character and intrinsic to "modern" law itself. In this they do differ from any explicit policy of state secularism or the no less explicit reformist will of some judges, which may change according to the historical period or to their personal dispositions. This paper comments on several judgments from the upper 
courts of India chosen from the end of the nineteenth century to the present day, with a view to discussing the disputed limits of this judicial intervention and the resulting entanglement between law and religion.

INDEX

Keywords: Hinduism, secularism, courts of law, essential practices, religious office, right to worship

\section{AUTHOR}

\section{GILLES TARABOUT}

Center for Ethnology and Comparative Sociology 